ICSHER JOURNAL Vol. 2, No. 2 (Dec., 2016): 54-59

\title{
Effect of Hands-on Activities on Achievement and Retention of Senior Secondary Chemistry Students in Stoichiometry
}

\author{
Josiah Ogbeba, Ph.D \& Oluwatosin Victor Ajayi \\ Department of Curriculum and Teaching, Benue State University, PMB 102119, Makurdi, Nigeria
}

Email: princeadeajayijunior@gmail.com

\begin{abstract}
The research was on the effect of hands-on activities on achievement and retention of senior secondary chemistry students in stoichiometry. A sample of 292 students from eight purposively selected secondary schools out of a population of 8,381 SS II students from zone C of Benue State, Nigeria was used for the study. The study adopted quasi-experimental research design. The instrument used for data collection was Stoichiometry Achievement Test (SAT) with the reliability value of 0.92 using Pearson Product Moment Coefficient. Two research questions and two null hypotheses guided the study. The research questions were answered using Mean and Standard Deviation scores while the hypotheses were tested at 0.05 level of significance using Analysis of Covariance (ANCOVA). The study revealed that students taught stoichiometry using hands-on activities had significantly higher mean achievement scores than those taught using demonstration method $(\mathrm{F}=555.374, \quad \mathrm{P}(\mathbf{0 . 0 0 0 1}<0.05)$ and students taught stoichiometry using hands-on activities had significantly higher mean retention scores than those taught using demonstration method $(\mathrm{F}=117.523, \mathrm{P}(\mathbf{0 . 0 0 0 1}<\mathbf{0 . 0 5})$. It was recommended that since hands-on activities method was found to be an effective method for improving students' achievement and retention in stoichiometry; Chemistry teacher's trainee should be trained on the use of hands-on activities and serving teachers should be encourage to use it.
\end{abstract}

Key words: Effect, hands-on activities, achievement, retention, stoichiometry.

\section{Introduction}

The world as a global community lays much emphasis on science and technology. The acquisition of science and technology at all levels of education depends on the teaching effectiveness measured in terms of the knowledge of what to teach, how to teach it and when to teach it (Archibong, 2009). Eriba (2007) describes science and technology as basic tools for industrial and national development. These if properly harnessed could bring about economic and social happiness by providing and improving the welfare of the citizenry. One of the broad aims of secondary education in Nigeria is rising up of generations of people who can think for themselves, respect the views and feelings of others, respect the dignity of labour, appreciate those values specified under Nigeria's broad national goals and live as good citizens (FGN, 2008).

Chang (2010) describes Chemistry as a core science subject needed as a pre-requisite to study any science or technological related discipline such as medicine, pharmacy, engineering, agriculture and all other science professions. Chemistry is one of the basic science subjects needed for sustainable development as its knowledge is important in the manufacturing of fertilizer, insecticides, food processing and storage, management of our natural resources, provision of food and health facilities as well as favourable living environment and it provides a natural link between home and school and the means through which students understand the world around them and explore the wider implications of science in relation to man. 
Despite the importance of Chemistry to mankind and the efforts of researchers to improve on its teaching and learning, achievement of students in the subject remains low in Nigeria. However, the West African Examination Council (WAEC) Chief Examiners report (2014/2015) on Chemistry result indicates that students are weak in some physical Chemistry concepts in the Senior Secondary School Certificate (SSCE) Chemistry syllabus such as chemical reactions, Stoichiometry, ionic equations, redox reactions and ionic theory. This situation of fluctuation in achievement of students in Chemistry have affected the education pursuits and aborted the ambition of many candidates that aspired to study professional courses. In this regard, Olorunyomi (2013) noted that demonstration method is popular in teaching SSCE physical Chemistry concept such as Stoichiometry. The researcher adds that demonstration method is teacher-centered as it does not involve the learners enough participation. The author also added that most Chemistry teachers adhere strictly to demonstration method of teaching whereby only the attention of the learners are invited towards the activities demonstrated by the teacher and students are not free to actively participate in such activities demonstrated by the teacher.

The high rates of failure recorded by students in private and public schools and colleges in Nigeria have been a major concern to researchers. Consequently, the low achievement in Chemistry in external examinations such as Senior Secondary Certificate Examination conducted by West Africa Examination Council and National Examination Council had been traced to the use of conventional teaching method that does not put into consideration the students' activity in teaching and learning processes. Chemistry being a core science subject is expected to serve as a base for scientific and technological knowledge that will enable the child to fit into the scientifically and technologically progressive society. A good number of students that offer science and science related courses in higher institutions are expected to pass Chemistry. Despite this expectation, low achievement in Chemistry by students appears to have persisted which is often blamed on poor teaching methods adopted.

Poor method of teaching invariably translates to students' poor achievement and inability to retain and to put into practice what is learnt in reality has become a hydra-headed problem. In most cases what is taught in classroom cannot be transferred to real life situation by students. In this regard, it would be pertinent that Chemistry teachers should acquire appropriate methods that could equip them in understanding principles and concepts for effective learning outcomes specifically in Stoichiometry. Henry (2007) describes Stoichiometry as an aspect of Chemistry that deals with calculations about the masses, or volume of reactants and products involved in a chemical reaction. The nation's quest for science and technological advancement will become a mirage, if effective modality is not put in place to incorporate innovative methods that promote active learning and considering the importance of chemistry in all round development, there is needs to make sure that chemistry is properly taught most especially the difficult concepts such as stoichiometry using innovative methods such as hands-on activities.

Tile (2013) describes hands-on activities as a situation whereby a learner uses his/her hands in carrying out activities that could enhance his/her experiences. By implication, concrete activities experiences are activities which involve doing using apparatus or objects. These include weighting, measuring, demonstrating, carrying out tests/experiments and any other concrete activities that could enhance students' learning experience in such concepts such as Stoichiometry. Abudullai (2013) describes hands-on activities as a method of teaching whereby students are engaged actively in class activities with the use of their hands and intellect under the guidance of the teacher. Therefore, this study examined the effect of hands-on activities on 
achievement and retention of senior secondary chemistry students in Stoichiometry.

\section{Research Questions}

The following research questions were answered in this study:

1. What is the difference in the mean achievement scores between students taught Stoichiometry using hands-on activities and those taught using demonstration method?

2. What is the difference in the mean retention scores between students taught Stoichiometry using hands-on activities and those taught using demonstration method?

\section{Hypotheses}

The following null hypotheses were tested at 0.05 level of significance:

1. There is no significant difference in the mean achievement scores between students taught Stoichiometry using hands-on activities and those taught using demonstration method.

2. There is no significant difference in the mean retention scores between students taught Stoichiometry using hands-on activities and those taught using demonstration method.

\section{Methodology}

The study used pre-test, post-test quasi experimental design. The pre-test score constituted the covariant of the post-test scores. In order to find out if the knowledge gained was retained, the post-test was reshuffled and administered as retention test to measure the subjects on retention. The experimental group was taught Stoichiometry using hands-on activities in line with lessons procedure prepared by the researcher while the control group was taught Stoichiometry using the demonstration lesson notes.

The study area was zone C of Benue State, Nigeria. The population of the study comprised all the 8,381 SSII students in the 136 granted aided schools. 292 students were purposively sampled from 8 of the schools that had some basic facilities and equipment in their laboratories. One instrument known as Stoichiometry Achievement Test (SAT) was used to collect data for this study.

SAT is a researcher made instrument that contains two sections. Section A contains bio-data information of the respondents, while section $B$ contains 30 objective items questions to which respondents are expected to provide the correct answer by filling in the gaps. SAT was validated by two experts from science education from Benue State University, Makurdi and one other from measurement and evaluation from University of Agriculture, Makurdi. Corrections and suggestions arising from these experts were used to review the instrument before it was used. Pearson product moment correlation coefficient was used to obtain the SAT reliability, which yielded a coefficient value of 0.92. Mean and Standard Deviation Scores of the collected data were used to answer the research questions while the null hypotheses were tested at 0.05 level of significance using Analysis of Covariance

\section{Results}

Presentations in this section are based on research questions and hypotheses:

\section{Research Question One}

What is the difference in the mean achievement scores between students taught Stoichiometry using hands-on activities and those taught using demonstration method? The answer to research question one is contained on Table 1. Table 1 revealed that, the overall mean difference between the two groups was 7.76 in favour of the hands-on activities group. It implies that the hands-on activities group achieved higher than the demonstration method group counterpart.

\section{Research Question Two}

What is the difference in the mean retention scores between students taught Stoichiometry using hands-on activities and those taught using demonstration method? The answer to research question two is presented on Table 2. The results on 
Table 2 revealed that, the overall mean difference between the two groups was 10.03 in favour of the hands-on activities group. It implies that the hands-on activities group had higher retention capacity than the demonstration method group.

\section{Hypothesis One}

There is no significant difference in the mean achievement scores between students taught stoichiometry using hands-on activities and those taught using discussion method. ANCOVA Tests result on Table 3 reveals that there is a significant difference between hands-on activities and demonstration methods of teaching in favour of hands-on activities $\mathrm{F}(1,291)=555.374, \quad \mathrm{P}(0.0001<0.05)$. The null hypothesis is therefore rejected. This implies that hands-on activities method is significantly more effective than demonstration method in achievement of students in Stoichiometry.

\section{Hypothesis Two}

There is no significant difference in the mean retention scores between students taught stoichiometry using hands-on activities and those taught using discussion method. ANCOVA Tests result in Table 4 reveals that there is significant difference in the mean retention scores between the students taught Stoichiometry using hands-on activities and those taught with demonstration method in favour of handson activities $\mathrm{F}(1,291)=117.523, \mathrm{P}(0.0001<0.05)$. The null hypothesis is therefore rejected. This means that hands-on activities significantly enhanced students' retention in Stoichiometry compared with demonstration method.

Table 1: Mean Achievement and Standard Deviation Scores of Students taught Stoichiometry using Hands-on Activities and Demonstration Method.

\begin{tabular}{lcccccc}
\hline Group & $\mathrm{N}$ & \multicolumn{2}{c}{ PRE-TEST } & \multicolumn{2}{c}{ POST-TEST } & \\
& & $\tilde{x}$ & $\delta$ & $\tilde{x}$ & $\delta$ & Mean Gain \\
\hline Hands-on Activities & 146 & 10.79 & 1.42 & 24.18 & 1.86 & 13.39 \\
Demonstration & 146 & 10.72 & 1.39 & 16.35 & 2.27 & 5.63 \\
Mean difference & & 0.07 & & 7.83 & & 7.76 \\
\hline
\end{tabular}

Table 2: Mean Retention and Standard Deviation Scores of Students taught Stoichiometry using Hands-on Activities and Demonstration Method.

\begin{tabular}{lcccccc}
\hline Group & $\mathrm{N}$ & \multicolumn{2}{c}{ PRE-TEST } & \multicolumn{2}{l}{ RETENTION-TEST } & \\
& & $\tilde{x}$ & $\delta$ & $\tilde{x}$ & $\delta$ & Mean Gain \\
& & & & & & \\
\hline Hands-on Activities & 146 & 10.79 & 1.42 & 24.33 & 1.77 & 13.54 \\
Demonstration & 146 & 10.72 & 1.39 & 14.23 & 2.32 & 3.51 \\
Mean difference & & 0.07 & & 10.10 & & 10.03 \\
& & & & & & \\
\hline
\end{tabular}


ICSHER JOURNAL Vol. 2, No. 2 (December, 2016)

Table 3: ANCOVA Tests for Mean Achievement Scores of Students taught Stoichiometry using Hands-on Activities and Demonstration Method

\begin{tabular}{lccccc}
\hline \multicolumn{1}{c}{ Source } & $\begin{array}{c}\text { Type III sum } \\
\text { of square }\end{array}$ & $d f$ & Mean Square & F & Sig \\
\hline Corrected model & $1700.332 \mathrm{a}$ & 2 & 425.083 & 135.821 & .000 \\
Intercept & 1792.021 & 1 & 1792.021 & 572.581 & .000 \\
Pre-test & 297.305 & 1 & 297.305 & 56.184 & .000 \\
Method & 1634.888 & 1 & 1634.888 & 555.374 & .000 \\
Error & 901.361 & 289 & 3.130 & & \\
Total & $\mathbf{1 0 9 3 6 6 . 0 0 0}$ & $\mathbf{2 9 2}$ & & & \\
Corrected Total & $\mathbf{2 6 0 1 . 6 9 3}$ & $\mathbf{2 9 1}$ & & & \\
\hline
\end{tabular}

a. $\quad$ R squared $=.654($ Adjusted $R$ Squared $=.649)$

Table 4: ANCOVA Tests for Mean Retention Scores of Students taught Stoichiometry using Hands-on Activities and Demonstration Method

\begin{tabular}{lccccc}
\hline \multicolumn{1}{c}{ Source } & $\begin{array}{c}\text { Type III sum } \\
\text { of square }\end{array}$ & $d f$ & Mean Square & F & Sig \\
\hline Corrected model & $3668.557 \mathrm{a}$ & 2 & 917.139 & 304.742 & .000 \\
Intercept & 1694.134 & 1 & 1694.134 & 562.912 & .000 \\
Pre-test & 202.482 & 1 & 202.482 & 51.825 & .000 \\
Method & 3536.532 & 1 & 3536.532 & 117.523 & .000 \\
Error & 866.754 & 289 & 3.010 & & \\
Total & $\mathbf{1 0 2 1 5 0 . 0 0 0}$ & $\mathbf{2 9 2}$ & & & \\
Corrected Total & $\mathbf{4 5 3 5 . 3 1 1}$ & $\mathbf{2 9 1}$ & & & \\
\hline
\end{tabular}

a. $\quad$ R squared $=.806$ (Adjusted $\mathrm{R}$ Squared $=.803$ )

\section{Discussion}

The findings of this study revealed that students taught Stoichiometry using hands-on activities achieved higher than their counterparts taught using demonstration method. This implies there is a significant difference in the mean achievement scores between students taught stoichiometry using hands-on activities and those taught using discussion method. This finding agrees with Martin (2011) and Mishira and Yadav (2013) who found that students achieved higher when exposed to hands-on activities than their counterparts that were exposed to traditional method in integrated science and elementary science respectively. 
The likely explanation for this outcome may be connected to the fact that the hands-on activities helped the learner to possess a meaningful in-depth knowledge of the content area when compared to the demonstration method.

It was also found that students exposed to hands-on activities have higher retention capacity than their counterpart that was exposed to demonstration method. This implies there is a significant difference in the mean retention scores between students taught stoichiometry using hands-on activities and those taught using discussion method. This finding agrees with Ali (2012) who found that students have higher retention capacity when they are actively engaged in solving problems through hands-on activities than when they become passive learners as obtained in the use of traditional method. The likely explanation for this outcome may also be connected to the fact that the use of hands-on activities in science teaching orient students towards reflecting on, interpreting and searching for solutions to the problems themselves when compared to the demonstration method. Therefore, this implies that hands-on activities method is a function of retention as it serves as a preservative factor of mind.

\section{Conclusion and Recommendation}

It is evident from the findings of this study that the use of hands-on activities enhanced students' achievement and retention in Stoichiometry than the use of demonstration method. Based on the conclusion, the following recommendations are advised:

Chemistry teacher's trainee should be trained on the application of hands-on activities. Serving teachers should employ the use of hands-on activities in teaching to enhance students' achievement and retention in Stoichiometry. Hands-on activities require that, there should be standard laboratory and sufficient instructional materials. Schools should provide good laboratory, sufficient instructional materials for students to carry out necessary activities in Stoichiometry through hands-on activities.

\section{References}

Abudullai, A.A. (2013). Teachers' involvement in the use of hand-on laboratory methods in teaching. International Journal of Education, 3(11), 234-237.

Ali, T.N. (2012). Impacts of hands-on activity-based and discussion methods on students' achievement in Basic Science. Unpublished Master dissertation, Adekunle Ajasin University, Ondo State University.

Archibong, A.U. (2009). The relative effectiveness of student-centered activity-based approach and lecture method on the cognitive achievements of Integrated Science students. Journal of Science Teachers Association of Nigeria, 32 (1\&2). 37-42.

Chang, R. (2010). Fundamental Chemistry, 6th ed. New York: McGraw Hill.

Eriba, J.O. (2007). Science, Technology and Mathematics Education as a tool for meeting the millennium development goals in Nigeria. Oju Journal of Science, Technology and Mathematics Education. 1(2), 1-5.

Federal Government of Nigeria (2008). National Policy on Education. Lagos: NERDC Press.

Henry, K.Y. (2007). Basic Stoichiometry. Retrieved on from http://www.psycnford.edu/Stoichiometry Martin, A.A. (2011). Effect of activity-based teaching method on cognitive achievement of Integrated Science students in Akure Local Government area of Ondo State. Unpublished M.Ed. dissertation, Federal University of Technology, Akure.

Mishra, S., \& Yadav, B. (2013). Effect of activitybased on students' achievement in Science at elementary stage. International Journal of Basic and Applied Science, 1(4),716-733.

Olorunyomi, A.A. (2013). Effect of experiential teaching method on students' achievement in Chemistry. Unpublished M.Ed dissertation, Ekiti State University, Ado Ekiti.

Tile, M.T. (2013). Effect of activity-based on psychomotor skills acquisition of senior secondary 2 in Biology. Unpublished M.Ed dissertation, Benue State University, Makurdi 